\title{
Preoperative pulmonary blood flow and one-lung anaesthesia
}

The distribution of pulmonary blood fow was measured in supine patients before surgery by means of lung perfusion scanning with ${ }^{99 m} T_{r}$-macroaggregated albumin int an attempt to predict values of $\mathrm{PaO}_{2}$ during subsequent one-lung ancesthesia. The $\mathrm{PaO}_{2}$ values during one-lung anaesthesia were well correlated with the preoperative lung perfusion partition ratios $(r=0.84$, $p<0.05$ ). In 9 of 40 patients, $\mathrm{PaO}_{2}$ was $<80 \mathrm{mmHg}$ during one-lung veritiation $\left(\mathrm{F}_{1} \mathrm{O}_{2} 0.99\right)$. In these patients the lung perfusion ratios of the dependent lung were as low as 41.0-48.2 per cen. These results indicate that preoperative measurement of pulmonary blood flow can predict values of $\mathrm{PaO}_{2}$ during one-Lung onaesthesia.

Severe hypoxaemia develops occasionally during onelung anaesthesia. Peltola' reported that during one-lung ventilation, 6 of 32 patients had $\mathrm{PaO}_{2}$ values less than $70 \mathrm{mmHg}$, in spite of breathing 100 per cent oxygen (lowest value $52.4 \mathrm{mmHg}$ ). Katz et al. ${ }^{2}$ reported that one-lung ventilation with an $\mathrm{FiO}_{2}$ of 0.99 resulted in a $\mathrm{PaO}_{2}$ of less than $80 \mathrm{mmHg}$ in 5 of 17 patients and in two patients $\mathrm{PaO}_{2}$ was less than $60 \mathrm{mmHg}$. In this study, the distribution of preoperative pulmonary blood flow was measured by means of lung perfusion scanning with ${ }^{99 \mathrm{~m}} \mathrm{Tc}$-macroaggregated-albumin ( $\left.{ }^{99 \mathrm{~m}} \mathrm{Tc}-\mathrm{MAA}\right)$ in an attempt to predict values of $\mathrm{PaO}_{2}$ during subsequent one-lung anaesthesia.

\section{Methods}

The investigation was performed in 40 adult patients between the ages of 27 and 74 years undergoing elective thoracotomy. Surgery was for cancer of the lung in 26 patients, empyema in eight patients and pulmonary tuberculosis in six patients.

Foljowing intravenous injection of approximately

\section{Key words}

ANAESTHESIA: one-lung anaesthesia; MEASUREMENT TECHNIQUES: regional pulmonary blood flow, lung perfusion scan.

From the Department of Anesthesiology, Tokyo National Chest Hospital, 3-1-1 Takcoka, Kiyose, Tokyo 204, Japan
$4 \mathrm{mCi}$ of ${ }^{99 n} \mathrm{Tc}-\mathrm{MAA}$ in $2 \mathrm{ml}$ saline with the patient in the supine position, images were taken in the posterior and anterior projections. The initial posterior image was accumulated for $400 \mathrm{~K}$ counts, which usually took one to two minutes. A subsequent scan was taken for the same length of time in the same position. Studies were performed with a standard large field-of-view camcra (Nuclear Ohio) centered over the $140 \mathrm{KeV}$ photopeak, using a 20 per cent window with a high-resolution, low-energy, parallel-hole collimator. The distribution of perfusion was evaluated by the mean values of radioactivity counted in two directions (anterior and posterior) over the thorax after intravenous administration of 99mTc-MAA.

Pulmonary function testing performed preoperatively with the patients seated included vital capacity (VC), forced vital capacity (FVC) and forced expiratory volume in ane second $\left(\mathrm{FEV}_{1}\right)$. No patient had cardiac disease.

All patients were premedicated with $0.5 \mathrm{mg}$ of atropine. Anaesthesia was induced with thiopentone and pancuronium and maintained with halothane and oxygen, delivered through a Robertshaw double-lumen tube. Tube position was confirmed by auscultation and visually at thoractomy. All patients were ventilated mechanically at 12-14 breath $\mathrm{min}^{-1}$ with a tidal volume of $10 \mathrm{ml} \cdot \mathrm{kg}^{-1}$. After thoractomy, one-lung ventilation was begun without alteration in tidal volume or rate.

Blood gas analyses were done before the start of anaesthesia $\left(\mathrm{FIO}_{2} 0.21\right)$, during two-lung ventilation in the lateral position, and during one-lung ventilation. The second blood samples were obtained 30 minutes after the start of two lung ventilation in the lateral position. The last blood samples were obtained 30 minutes after collapse of the non-dependent lung. In ten patients, blood samples were obtained directly from the pulmonary artery in the operative field in order to calculate the shunt ratio. All blood samples were taken before either occlusion or division of the pulmonary artery.

Physiological shunt (Q்/Qt) was calculated using standard equations. *

${ }^{*} \dot{\mathrm{Q}} / \mathrm{Q} \mathrm{i}=\left(\mathrm{CcO}_{2}-\mathrm{CaO}_{2}\right) /\left(\mathrm{CcO}_{2}-\mathrm{CrO}_{2}\right) \times 100$

$\mathrm{CcO}_{2}=\mathrm{Hb} \times 1.39+0.003 \times \mathrm{PAO}_{2}$

$\left(\mathrm{FlO}_{2} 0.99\right.$, respiratory quoticnt 0.8$)$ 
Data are expressed as means \pm SE. Statistical analyses were done with Student's 1 test and the level of significance was defined as $p<0.05$.

\section{Results}

Preoperative distribution of pulmonary perfusion The ratio of perfusion partition between the dependent and the non-dependent lung was $64.9 \pm 2.9$ per cent. Twenty-six patients had the abnormality in the right lung and in these patients the ratio of perfusion partition was $61.0 \pm 4.2$ per cent. In patients with cancer of the lung, the ratio of perfusion partition was $56.9 \pm 2.6$ per cent. In empyema, the ratio was as high as $85.2 \pm 4.9$ per cent, probably because the effective pulmonary alveolar area was small in the non-dependent lung and in some the blood flow was almost immeasurable.

\section{Blood gas analyses}

Preoperative values of $\mathrm{pH}$ and $\mathrm{PaO}_{2}$ were $7.38 \pm 0.01$ and $40 \pm 1 \mathrm{mmHg}$, respectively. These values during twolung ventilation were $7.38 \pm 0.02$ and $40 \pm 2 \mathrm{mmHg}$, during one-lung ventilation were $7.37 \pm 0.01$ and $39 \pm$ $1 \mathrm{mmHg}$. None of these variables changed significantly throughout the subsequent study periods.

The mean value of $\mathrm{PaO}_{2}$ was $79 \pm 4 \mathrm{mmHg}$ preoperatively $\left(\mathrm{FlO}_{2} 0.2 \mathrm{l}\right), 385 \pm 9 \mathrm{mmHg}$ duning two-lung ventilation $\left(\mathrm{FIO}_{2} 0.99\right)$ and $211 \pm 19 \mathrm{mmHg}$ during onelung ventilation $\left(\mathrm{FIO}_{2} 0.99\right)$. In patients with empyema, higher $\mathrm{PaO}_{2}$ values $(269 \pm 22 \mathrm{mmHg})$ during one-lung ventilation were noted than in palients with cancer of the lung $(171 \pm 21 \mathrm{mmHg})$. In 9 of 40 patients, $\mathrm{PaO}_{2}$ was less than $80 \mathrm{mmHg}$ during one-lung ventilation and the lowest values was $53 \mathrm{mmHg}$. In these cases the lung perfusion ratios of the dependent lung were as low as $41-48$ per cent.

The shunt ratio obtained in ten cases by blood sampling from the pulmonary artery, averaged $41 \pm 4$ per cent during one-lung ventilation.

\section{Correlation coefficients}

The values of $\mathrm{PaO}_{2}$ during one-lung andesthesia were well correlated with the preoperative lung perfusion partition ratios as shown in Figure $1(\mathrm{r}=0.84, \mathrm{p}<0.05)$. An inverse correlation was noted between $\mathrm{PaO}_{2}$ during one-lung ventilation and both the preoperative percentage of predicted VC (\%VC, $\mathrm{r}=-0.59, \mathrm{p}<0.05)$ (Figure 2) and the percentage of predicted FVC $(\mathrm{r}=-0.68, \mathrm{p}<$ 0.05 ). No significant correlation of $\mathrm{PaO}_{2}$ during one-lung ventilation was noted either with preoperative $\mathrm{PaO}_{2}$ or preoperative $\mathrm{FEV}_{1} / \mathrm{FVC}$. A highly significant inverse correlation was noted between preoperative lung perfu-

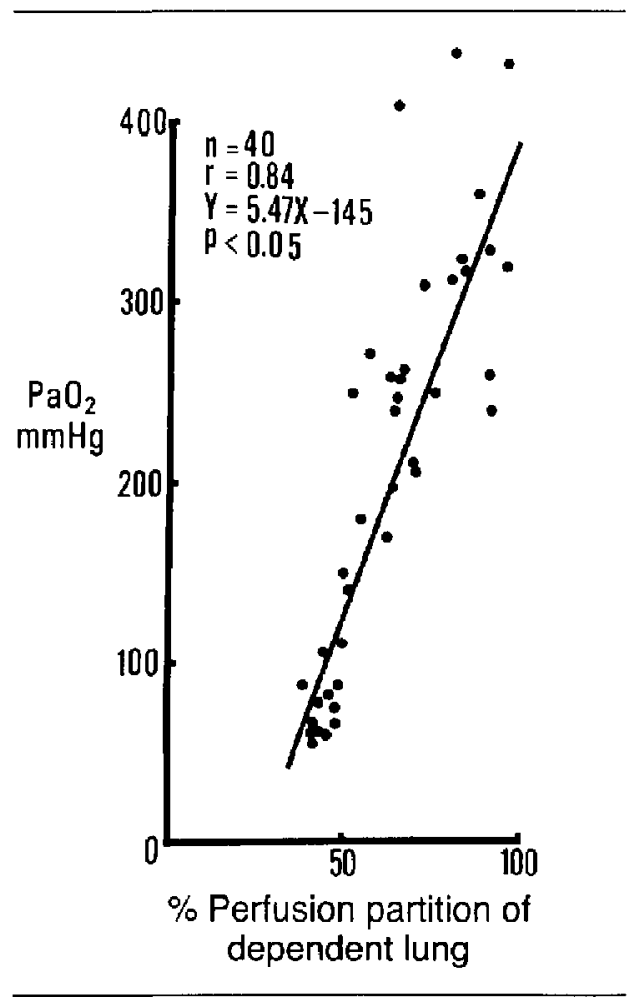

FIGURE I A significant correlation was found between the perfusion partition of the dependent lung and $\mathrm{PaO}_{2}$ during one-lung anaesthesia. In 9 of 40 patients, $\mathrm{PaO}_{2}$ was less than $80 \mathrm{mmHg}$ during one-lung ventilation and in these cases the lung perfusion ratios of the dependen lung were as low as $41-48$ per cent.

sion partition ratios and $\dot{\mathrm{Q}}$ / $\dot{\mathrm{Q}} \mathrm{t}$ during one-lung ventilation $(r=-0.86, p<0.05)$.

\section{Discussion}

One-lung anaesthesia has the disadvantage of producing impaired pulmonary oxygen exchange and an increase in the alveolar-to-arterial oxygen pressure difference $\mathrm{P}(\mathrm{A}-\mathrm{a}) \mathrm{O}_{2} \cdot{ }^{3-5}$ In this study, one-lung anaesthesia with an $\mathrm{FiO}_{2}$ of 0.99 resulted in $\mathrm{PaO}_{2}$ values of less than $80 \mathrm{mmHg}$ in 9 of 40 patients. As expected, a high correlation between preoperative blood flow to the dependent lung and $\mathrm{PaO}_{2}$ during one-lung ventilation was noted. Also, there was a high inverse correlation between preopcrative blood flow to the dependent lung and QQs/Qt during one-lung ventilation. Our data suggest that preoperative measurement of pulmonary blood flow can help predict values of $\mathrm{PaO}_{2}$ during one-lung anaesthesia. 


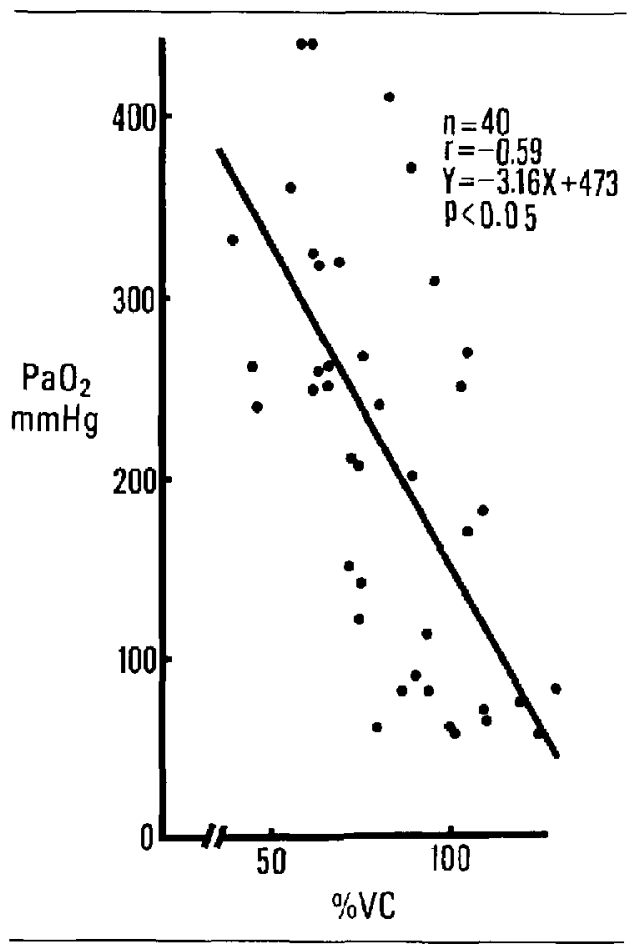

FIGURE 2 An inverse correlation was noted between the preoperative percentage of predicted $\mathrm{VC}(\% \mathrm{VC})$ and $\mathrm{PaO}_{2}$ during onelung anacsthesia.

Flacke et al. ${ }^{6}$ reported a significant positive correlation between $\mathrm{PaO}_{2}$ during one-lung ventilation and both the preoperative $\mathrm{FVC}$ and $\mathrm{PaO}_{2}$ during two-lung ventilation as well as an exponential relationship to preoperative $\mathrm{PaO}_{2}$. However, Katz et al. ${ }^{2}$ reported that $\mathrm{PaO}_{2}$ during one-lung ventilation correlated inversely with the percentage of predicted FEV $(R=-0.66, p<0.005)$ and the percentage of predicted FVC $(\mathrm{s}=-0.51, \mathrm{p}<0.05)$, but did not correlate significantly with $\mathrm{FEV}_{1} / \mathrm{FVC}$, preoperative $\mathrm{PaO}_{2}$, or $\mathrm{PaO}_{2}$ during two-lung ventilation. The findings in the present study of an inverse corrclation between $\mathrm{PaO}_{2}$ during one-lung ventilation and both the $\% \mathrm{VC}$ and the percentage of predicted FVC and absence of correlation between $\mathrm{PaO}_{2}$ during one-lung ventilation and FEV $1 /$ FVC or preoperative $\mathrm{PaO}_{2}$ agree with the report of Katz et al. It is possible that some patients with a low $\% \mathrm{VC}$ had this reduction because of unilateral restrictive pulmonary disease and the preoperative pulmonary blood flow to the operative side was less, therefore values of
$\mathrm{PaO}_{2}$ remained high during one-lung ventilation. There are, however, so many factors affecting oxygenation that frequent monitoring of blood gases is mandatory.

\section{Acknowledgment}

The author gratefully acknowledges manuscript reviews by Tatsushi Fujita, M.D., Gunma University.

\section{References}

I Peltola $K$. Central hemodynamics and oxygenation during thoracic anesthesia. Acta Anaesthesiol Scand 1983; 27

(Suppl 77): 1-51.

2 Katz JA, Laverne RG, Fairley MB et al. Pulmonary oxygen exchange during endobronchial anesthesia. Anesthesiology 1982; 56: 164-71.

3 Brown RA, Caton DV, Ashworth EJ. A study of oxygenation during tharactomy. Can Anaesth Soc J 1968; 15: $468-77$

4 Tarhan $S$, Lundborg RO. Carlens endobronchial catheter versus regular encotracheal tube during thoracic surgery: a comparison of blood gas tensions and pulmonary shunting. Can Anaesth Soc J 1971; 18: 594-9.

5 Lunding $M$, Fernandes $A$. Arterial oxygen tension and acid-basc status during thoracic anaesthesia. Acta Anaesthesiol Scand 1967; 11: 43-55.

6 Flacke JW, Thompson DS, Read RC. Influence of tidal volume and pulmonary artery occlusion on arterial oxygenation during endobronchial anesthesia. South Med J 1976; 69: 619-26.

\section{Résumé}

On a mesuré, avant la chirurgie, la distribution du débit sanguin pulmonaire en utilisant un balayage de perfusion pulmonaire avec de l'albumine ${ }^{99 m}$ TC-macroagrége chez un patiens en dérubitus dorsal, afin d'essayer de prédire les valeurs de la $\mathrm{PaO}_{2}$ durant une anesthésic à un poumon subsequente. Durant l'anesthésie à un poumon, les valeurs de la $\mathrm{PaO}_{2}$ correspon. daient bien à celles des rapports de partition de la perfusion pulmonaire príopératoire $(r=0.84, p<0.05)$. Neuf des 40 patients ont eu une $\mathrm{PaO}_{2}$ de moins de $80 \mathrm{mmHg}$ durant la ventilation à un poumon $\left(\mathrm{F}_{1} \mathrm{O}_{2}\right.$ 0.99). Dans ces cas là, les rapports de perfusion pulmonaire du poumon dépendant étaient aussi peu élevés que 41.0-48.2 per cent. Ces résultats indiquent que l'on peut prédire les valeurs de la $\mathrm{PaO}_{2}$ durant une anesthésie à un pounon en mesurant le débit sanguin pul. monaire en période préopératoire. 